\title{
Translations, Sources, and Abbreviations
}

Unless otherwise indicated, Augustine's writings are quoted from these translations:

Against the Academics [Contra academicos], trans. John J. O'Meara. Ancient Christian Writers, no. 12. New York: Newman Press, 1951.

The Catholic Way of Life [De moribus ecclesiae], trans. Donald A. Gallagher and Idella J. Gallagher. Fathers of the Church, vol. 56. Washington, D.C.: Catholic University of America Press, 1966.

Christian Instruction [De doctrina christiana], trans. John J. Gavigan. Fathers of the Church, vol. 2. Washington, D.C.: Catholic University of America Press, 1950.

City of God, trans. Gerald G. Walsh et al. Garden City: Image Books, 1958.

Concerning the Teacher [De magistro], trans. G. C. Leckie. Basic Writings of Saint Augustine, ed. Whitney J. Oates, 1:361-95. New York: Random House, 1948.

Confessions, trans. R. S. Pine-Coffin. Harmondsworth: Penguin, 1961 .

Eighty-Three Different Questions [De diversis quaestionibus LXXXIII], trans. David L. Mosher. Fathers of the Church, vol. 70. Washington, D.C.: Catholic University of America Press, 1982.

Homilies on the Gospel of John [In joannis evangelium], trans. John Gibb and James Innes. A Select Library of the Nicene and Post-Nicene Fathers, ed. Philip Schaff, 7:7-452. New York: Christian Literature, 1888.

The Immortality of the Soul [De immortalitate animae], trans. Ludwig Schopp. New York: Fathers of the Church, 1947, 15-47. 
Letters [Epistola], trans. Wilfrid Parsons. Fathers of the Church, vols. 12, 18, 20, 30, 32. Washington, D.C.: Catholic University of America Press, $1951-56$.

The Literal Meaning of Genesis [De genesi ad litteram], trans. John Hammond Taylor. Ancient Christian Writers, vols. 41-42. New York: Newman Press, 1982.

The Lord's Sermon on the Mount [De sermone domini in monte], trans. John J. Jepson. Ancient Christian Writers, no. 5. New York: Newman Press, 1948.

Lying [De mendacio], in Treatises on Various Subjects, trans. Mary Sarah Muldowney. Fathers of the Church, 16:47-110. Washington, D.C.: Catholic University of America Press, 1952.

Of True Religion [De vera religione], trans. John H. S. Burleigh. Augustine: Earlier Writings, in The Library of Christian Classics, 6:22583. Philadelphia: Westminster Press, 1953.

On Free Choice of the Will [De libero arbitrio], trans. Anna S. Benjamin and L. H. Hackstaff. Indianapolis: Bobbs-Merrill, 1964.

On Man's Perfection in Righteousness [De perfectione justiciae hominis], trans. Peter Holmes et al. A Select Library of the Nicene and Post-Nicene Fathers, ed. Philip Schaff, 5:159-76. New York: Christian Literature, 1887.

On the Greatness of the Soul [De quantitate animae], trans. Joseph M. Colleran. Ancient Christian Writers, no. 9. New York: Newman Press, 1950 .

On the Soul and Its Origin [De anima et ejus origine], trans. Peter Holmes et al. A Select Library of the Nicene and Post-Nicene Fathers, ed. Philip Schaff, 5:315-71. New York: Christian Literature, 1887.

On the Spirit and the Letter [De spiritu et littera], trans. P. Holmes. Basic Writings of Saint Augustine, ed. Whitney J. Oates, 1:461-518. New York: Random House, 1948.

The Retractions [Retractiones], trans. Mary Inez Bogan. Fathers of the Church, vol. 60. Washington, D.C.: Catholic University of America Press, 1968.

The Trinity [De trinitate], trans. Stephen McKenna. Fathers of the Church, vol. 45. Washington, D.C.: Catholic University of America Press, 1963.

The Usefulness of Belief [De utilitate credendi], in Augustine: Earlier Writings, trans. John H. S. Burleigh. Library of Christian Classics, 6:287-323. Philadelphia: Westminster Press, 1953.

All citations of Descartes's works include a reference to the standard edition of Descartes, Oeuvres de Descartes, ed. Charles Adam and Paul Tannery, 12 vols. (Paris: Vrin, 1964-76). Fol- 
lowing custom, I give those references as "AT" plus the volume and page of the passage.

Most quotations from Descartes are given in the translation of John Cottingham, Robert Stoothoff, and Dugald Murdoch, The Philosophical Writings of Descartes, 2 vols. (Cambridge University Press, 1985). I refer to passages in this translation as "CSM" plus the volume and page.

CSM does not include letters. Where possible I take quotations of letters from Descartes: Philosophical Letters, trans. Anthony Kenny (Oxford: Clarendon Press, 1970). I cite passages from Kenny's collection as "K" plus the page. 



\section{T H O U G H T $\mathrm{T}$ E G O}

in Augustine and Descartes 
